\title{
INNOVATION OF THE EDUCATIONAL CONTENT IN TECHNICAL EDUCATION AS A REACTION ON THE CURRENT PRACTICE DEMANDS
}

\section{Vladimír SOTÁK - Mária MUCHOVÁ}

\begin{abstract}
Application of the up-to-date knowledge in the area of technologies into the production practice within the context of international economic situation raises the need for re-evaluation of the content of technical education. Education should be in concord with the current practice demands, better in advance. To rethink and to improve information flow it is the way to do it.

Nowadays, the core of technical education is united in understanding of principal trends and demands for education. On the other side, there is an obvious clash of interests when talking of various conditions for practical realization of educational intention.

Department of Information Technologies tries to react on changes caused by the free market. Notwithstanding of the fact of principal specialization in preparation of teachers of technical vocational subjects, it was forced to enrich the content of curriculum above the common borders. This content is a result of theory, representing by Department of technics and IT, and practice, representing by Delta electronics (Slovakia) s.r.o., cooperation.
\end{abstract}

Key words: labour market, educational content, information flow.

\section{INOVÁCIA OBSAHU VYUČOVANIA TECHNICKÉHO VZDELÁVANIA V REAKCII NA AKTUÁLNE POŽIADAVKY PRAXE}

Resumé: Aplikovanie najnovších poznatkov technológií do výrobnej praxe vyvoláva v kontexte medzinárodnej ekonomickej situácie aj potrebu prehodnotenia obsahu náplne vyučovania technického vzdelávania. Vzdelávanie by malo byt'v súlade s požiadavkami praxe, v ideálnom pripade by obsah vzdelávania mal byt'v predstihu. K tomu je potrebné prehodnotit' a skvalitnit' prácu s informáciami.

Súčasná báza technickej výchovy je na jednej strane jednotná v chápaní základných trendov a požiadaviek na vzdelávanie. Na druhe strane existuje diferenciácia $v$ zmysle rozličných podmienok pre realizáciu vzdelávacích zámerov. Katedra techniky a informačných technológií sa snaži reagovat' na zmeny vyvolané trhovým prostredím v rámci svojich podmienok. Napriek tomu, že by sa mala primárne špecializovat' na prípravu učitel’ov technických odborných predmetov, bola katedra reálne prinútená zamerat' obsah vzdelávania smerom, ktorý významne prekračuje hranice stanovené pre prípravu učitelov. Tento príspevok vznikol na základe spolupráce teórie, reprezentovanej Katedrou techniky a informačných technológií s praxou, ktorú reprezentuje $v$ našom prípade firma Delta electronics (Slovakia) s.r.o.

Kl’účové slová: trh práce, obsah vzdelávania, tok informácií.

\section{Úvod}

Pracoviská podobného charakteru ako Katedra techniky a informačných technológií (KTaIT) Pedagogickej fakulty Univerzity Konštantína Filozofa v Nitre majú v súčasnosti v Slovenskej republike nel'ahkú pozíciu a to z viacerých dôvodov. Hlavný problem spočíva $\mathrm{v}$ tom, že napriek všestrannému deklarovaniu významu techniky a potreby výchovy technicky vzdelanej mládeže, je základný kameň technického vzdelávania - technická výchova na základných školách - okresaný na minimum, ktoré nemôže slúžit' ako solídny podklad pre vyššie stupne. $\mathrm{S}$ tým súvisí nepríjemný sprievodný jav, ktorý spočíva $\mathrm{v}$ tom, že realizovat' sa v plnej šírke v rámci predmetu, ktorý je zatláčaný do ústrania, napríklad v oblasti vedecko-výskumnej činnosti, je čoraz zložitejšie. Najmä s prihliadnutím na schopnost' obstát' $\mathrm{v}$ tejto oblasti $\mathrm{v}$ konkurencii $\mathrm{s}$ inými pracoviskami zameranými na technické vzdelávanie. Východisko vidíme $\mathrm{v}$ posune prípravy našich študentov mimo zavedené hranice "tradičnej" technickej výchovy. V jadre 
tohoto príspevku je naznačený jeden zo smerov, ktorým by sme sa chceli v budúcnosti uberat'.

\section{Spolupráca teórie a praxe $\mathrm{v}$ podmienkach KTaIT}

Vopred sa žiada uviest', že v rámci tohoto príspevku nie je pokrytá celá škála predmetov realizovaných na katedre. Autori sa zmieňujú len o vybranej oblasti, v ktorej nové smerovanie začínajú osobne realizovat'. Ide o oblast' ohraničenú okruhom technika, životné prostredie, pracovné prostredie, bezpečnost' pri práci.

V zjednodušenej podobe sa dá uviest', že tradičný prístup $\mathrm{k}$ vzdelávaniu $\mathrm{v}$ predmetnej oblasti po roku 1989 viedol cez zvládnutie tzv. Environmentálneho minima, čo sú $\mathrm{v}$ podstate učebné osnovy pre enviromnentálnu výchovu na základných a stredných školách schválené Ministersvom školstva Slovenskej republiky v roku 1996. Už takmer dvadsat' rokov je tento prístup prekonaný. Takéto zjednodušené chápanie sa stalo brzdou prinajmenšom v momente, ked' bol dosiahnutý medzník, ktorý bol reprezentovaný presadením predmetu environmentálna výchova do systému vzdelávania.

Kvalitatívny posun $\mathrm{v}$ danej oblasti bol $\mathrm{v}$ nasledujúcom období reprezentovaný postupným budovaním mezipredmetových vzt'ahov a zdôrazňovaním úlohy techniky ako fenoménu, ktorý rozhodujúcou mierou ovplyvňuje biosféru. Ekonomická aktivita človeka postupom času pretvorila značnú čast' biosféry natol'ko, že bolo nutné prehodnotit' niektoré tradičné náhl'ady a priznat', že náš život prebieha v špecificky pretvorenej biosfére, ktorou je technosféra. V tej súvislosti začali vznikat' nové predmety a oblasti bádania a do výučby nových environmentálne orientovaných predmetov sa začal vnášat' nový obsah. Tento obsah bol však stále postavený prevažne na akademických základoch, ktoré sa vyznačovali vysokou úrovňou kvality informácií a vysokým stupňom aktuálnosti, no vo väčšine prípadov, nevynímajúc naše pracovisko, absentovalo užšie prepojenie s praxou.

Ak sme chceli prekročit' tradičný rámec obsahovej náplne, nemohli sme sa zaobíst' bez zmeny v podobe patričnej externej podpory.

Túto zmenu reprezentuje $\mathrm{v}$ súčasnosti predovšetkým:

- nový prístup k toku informácií,

- priama spolupráca s praxou.
Základná myšlienka prepojenia $\mathrm{s}$ praxou spočívala v uvedomení si možností jednotlivých spolupracujúcich strán. Pedagogické pracoviská nášho typu môžu vstupovat' do vzt'ahu ako poskytovatelia didaktického know how. Prax, reprezentovaná výrobnými jednotkami, vstupuje do vzt'ahu ako zdroj informácií o realite. Tieto následne slúžia ako regulátor, resp. usmerňovač, teoretickej prípravy. V neposlednom rade je pre teoretickú základňu dôležité, že prax môže poskytnút' reálnu materiálnu podporu $\mathrm{v}$ rôznych podobách, no $\mathrm{v}$ tomto príspevku sa zameriavame len na tok informácií.

V klasickom chápaní by tok informácií mohol byt' zjednodušene popísaný nasledovne:

- zdroj informácií - analógové a elektronické bežne dostupné informačné zdroje, získava pedagóg z kníh, časopisov, CD, internetu a pod.

- informačný tok smeruje od učitel'a $\mathrm{k}$ študentovi.

Nový prístup rozširuje informačnú bázu a zdanlivo ju komplikuje:

- medzi katedrou a podnikom prebieha permanentná výmena informácí́, podnik je informovaný o požiadavkách na informácie zo strany katedry (pričom tieto požiadavky sú do istej miery podmienené platnými osnovami) a následne poskytuje informácie, ktoré nielen spíňajú definovanú požiadavku ale navyše obsahujú impulz pre inováciu učebných osnov,

- do systému vstupuje tretí prvok - externý informačný zdroj podniku, informačná výmena prebieha medzi podnikom a jeho zdrojom informácií (výrobná sféra je vo svojej činnosti korigovaná príslušnou legislatívou a technickými normami),

- v následnom informačnom cykle medzi katedrou a podnikom je obsiahnutá nová informácia, ktorú podnik získal z externého zdroja.

Výsledný efekt spočíva $\mathrm{v}$ tom, že študent ako konečný príjemca má $\mathrm{k}$ dispozícii informácie $\mathrm{V}$ súlade $\mathrm{s}$ realitou $\mathrm{a}$ teda s požiadavkami praxe.

Pre ilustráciu uvádzame konkrétny príklad:

V praxi vzniká dopyt po pracovníkoch v oblasti bezpečnosti a ochrany zdravia pri práci (BOZP). Jednou zo základných kvalifikačných požiadaviek je technické vzdelanie $\mathrm{v}$ rozsahu, ktorý môže kvalifikovane poskytnút' pracovisko nášho typu. Realizácia vzdelávacieho zámeru môže prebehnút' v dvoch líniách, pričom sa nevylučuje ich paralelná 
existencia. Prvú predstavuje špecializované štúdium v odbore BOZP, druhú líniu môže reprezentovat' nasledovný zjednodušený model (zjednodušenie spočíva $\mathrm{v}$ tom, že model demonštrujeme len na jednom predmete:

Výučba na tému technika a životné prostredie je usmerňovaná $\mathrm{v}$ línii biosféra technosféra - pracovisko ako súčast' technosféry - bezpečnost' a ochrana zdravia pri práci.

Z katedry je e-mailom odoslaná požiadavka na najnovšie informácie o predpisoch a normách $\mathrm{v}$ oblasti pracovného prostredia adresovaná na kvalifikovaného pracovníka, zodpovedného vo výrobnom podniku za predmetnú problematiku. Spätne prichádzajú na katedru v elektronickej podobe najnovšie informácie o tom, čo je $\mathrm{v}$ danej oblasti momentálne platné $\mathrm{v}$ praxi. Klasické zdroje informácií sú obohatené, aktualizované a prinajmenšom je verifikovaná ich platnost'. Pedagóg má istotu, že študentom poskytuje relevantnú informáciu. Pri dohode o permanentnom informačnom toku prichádzajú na tú istú tému d’alšie (a novšie) informácie krátko potom, ako ich pracovník podniku získa z externého zdroja. Táto forma spolupráce je výhodná napríklad $\mathrm{v}$ oblasti technických normiem, ktoré sú často pre školstvo t'ažšie dostupné najmä $\mathrm{Z}$ finančných dôvodov. $\mathrm{V}$ opačnom smere môže prúdit' tok informácií napríklad vo forme poradenstva $\mathrm{v}$ oblasti využívania informačných technológií.

Smerovanie nášho prístupu sme konfrontovali s relevantnými domácimi i zahraničnými informačnými zdrojmi. Problematike vzdelávania v oblasti, ktorou sa zaoberáme sa venujú viacerí odborníci. Prístupy, ktoré prezentujú vo svojich prácach [1], [2], [3], [4], [5], [6], [7] korešpondujú s našou filozofiou a sú pre našu prácu užitočným zdrojom informácií.

\section{Záver}

KTaIT sa podobne ako d'alšie sesterské pracoviská snaží rozšírit' možnosti uplatnenia svojich absolventov v rámci nových podmienok pracovného trhu. Rozsah a obsah poskytovaných informácií $\mathrm{v}$ rámci vyučovacieho procesu by mal zabezpečt' dostatočnú informačnú základňu, ktorá po stránke kvantity a kvality zaistí aby absolvent našiel uplatnenie $\mathrm{v}$ praxi. Jednou z potenciálnych možností ako to dosiahnut' je prehodnotenie existujúcich informačných tokov.

\section{Literatúra}

(1) Koncepcia bezpečnosti a ochrany zdravia pri práci v Slovenskej republike na roky 2008 -2012. [cit. 2008-12-2].

<http://www.rokovanie.sk/appl/material.nsf/0/1 93554FC1C08AF50C12573F40027EBDB/\$FI

LE/Zdroj.html>

(2) POLÁK, M.: Vysoké školy na Sovensku šance a riziká. [c 28.9.2005, TREND / Matej Polák]. [cit. 2008-12-9]. <http://www.etrend.sk/ekonomika/slovensko/vy soke-skoly-na-slovensku-sance-a-rizikadiskusia/55557.html>

(3) PODSTUPKA, I.:Vzt'ah škôl a priemyslu je platonický. [c 22.6. 2006 HNonline]. [cit. 200812-2]. <http://hnonline.sk/1-1002563018738470-k04100 detail-18>

(4) SINAY, J.: Podiel univerzít na výskumnej činnosti BOZP na Slovensku. In XXI. medzinárodná konferencia Aktuálne otázky bezpečnosti práce (New trends in safety and health). Zborník referátov $z$ konferencie usporiadanej s podporou Európskej agentúry pre bezpečnost' a ochranu zdravia pri práci, Národný inšpektorát práce, Technická univerzita $v$ Košiciach, Asociácia pre bezpečnost' a ochranu zdravia pri práci a Inštitút pre výskum práce a rodiny. Štrbské Pleso - Vysoké Tatry, 3.-5.11. 2008. s. 161165. ISBN 978-80-553-0099-3

(5) BALOG, K.: Výskum v oblasti bezpečnostných a environmentálnych aspektov. In XXI. medzinárodná konferencia Aktuálne otázky bezpečnosti práce (New trends in safety and health). Zborník referátov z konferencie usporiadanej s podporou Európskej agentúry pre bezpečnost' a ochranu zdravia pri práci, Národný inšpektorát práce, Technická univerzita $v$ Košiciach, Asociácia pre bezpečnost' a ochranu zdravia pri práci a Inštitút pre výskum práce a rodiny. Štrbské Pleso - Vysoké Tatry, 3.-5.11. 2008. s. 166170. ISBN 978-80-553-0099-3

(6) KÖRBLER, R.: Implementation Prevention Training at Vocational Schools - Part of the European Strategy 2007 - 2012. In XXI. medzinárodná konferencia Aktuálne otázky bezpečnosti práce (New trends in safety and health). Zborník referátov $z$ konferencie usporiadanej s podporou Európskej agentúry pre bezpečnost' a ochranu zdravia pri práci, Národný inšpektorát práce, Technická 
univerzita $v$ Košiciach, Asociácia pre bezpečnost' a ochranu zdravia pri práci a Inštitút pre výskum práce a rodiny. Štrbské Pleso - Vysoké Tatry, 3.-5.11. 2008. s. 54-57. ISBN 978-80-553-0099-3

(7) HALE, A., HARVEY, H., MENNOZI, M., MIGUEL,S., BIANCHI, G.: Certification of Safety Professionals at the European Level. In XXI. medzinárodná konferencia Aktuálne otázky bezpečnosti práce (New trends in safety and health). Zborník referátov $z$ konferencie usporiadanej s podporou Európskej agentúry pre bezpečnost' a ochranu zdravia pri práci, Národný inšpektorát práce, Technická univerzita $v$ Košiciach, Asociácia pre bezpečnost' a ochranu zdravia pri práci a Inštitút pre výskum práce a rodiny. Štrbské Pleso - Vysoké Tatry, 3.-5.11. 2008. s. 26-34. ISBN 978-80-553-0099-3 doc. Ing. Vladimír Soták, CSc.

Katedra techniky a informačných technológií, PF UKF v Nitre

Dražovská cesta 4 Nitra

Telefón: +42137903038828

E-mail: vsotak@ukf.sk

Web: www.ukf.sk

Ing. Mária Muchová

Engineer for Energetics, Health and Safety

Delta Electronics (Slovakia) s.r.o.

Priemyselna ulica 4600/1, SK - 01841

Dubnica nad Vahom

$T+421424661441, F+421424661131$

$\mathrm{M}+421911660194$

maria.muchova@delta-es.com

www.deltaenergysystems.com 